\section{SOI: 1.1/TAS DOI: 10.15863/TAS International Scientific Journal Theoretical \& Applied Science}

\author{
p-ISSN: 2308-4944 (print) e-ISSN: 2409-0085 (online) \\ Year: $2018 \quad$ Issue: $01 \quad$ Volume: 57
}

Published: $30.01 .2018 \quad$ http://T-Science.org

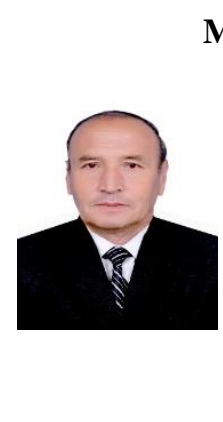

Muso Muydinbaevich Todzhikhodzhaev

Scientific researcher of

Namangan State University Department of Germann and French aziz.1959@mail.ru phone: +99890 2787390

SECTION 29. Literature. Folklore. Translation Studies.

\title{
THE EUROPEAN RESEACHER OF UZBEK LANGUAGE AND LITERATURE
}

Abstract: The article analyzes the work of the outstanding German orientalist Martin Hartmann in of turcology. Well - mastered the oriental poetry Hartmann translated from Old Uzbek into German the works of great Uzbek classics. Based on the results of the 7-month trip to Central Asia,dozens of fairy tales, myths, anecdotes and stories of Turkic peoples were collected, analyzed and translated.

Key words: orientalist, the author of the textbook "Chagatai language", direct translations from Old Uzbek into German, studies of Sufi poets of the East, translations of the ghazels by Alisher Navoiy, travel to Central Asia.

Language: Russian

Citation: Todzhikhodzhaev MM (2018) THE EUROPEAN RESEACHER OF UZBEK LANGUAGE AND LITERATURE. ISJ Theoretical \& Applied Science, 01 (57): 172-175.

Soi: http://s-o-i.org/1.1/TAS-01-57-31 Doi: crossef https://dx.doi.org/10.15863/TAS.2018.01.57.31

\section{ЕВРОПЕЙСКИЙ ИССЛЕДОВАТЕЛЬ УЗБЕКСКОГО ЯЗЫКА И ЛИТЕРАТУРУ}

Аннотация: В статье анализируется творчество выдающегося немецкого востоковеда профессора Мартина Хартманна в области тюркологии. Хартманн, хорошо освоивший восточную поэзию, создал учебник "Чагатайский язык», перевел со староузбекского языка на немецкий произведения великих узбекских классиков. По итогам 7 месячной поездки в Центральную Азию было собрано, проанализировано и переведено десятки сказок, мифов, анекдотов и рассказов тюркских народов.

Ключевые слова: востоковед, автор учебника "Чагатайский язык», непосредственные переводы с узбекского языка на немецкий, изучения суфийских поэтов Востока, переводы газелей Алишера Навоий.

\section{Introduction}

Заведующий кафедрой Семинарии восточных языков Берлинского университета Германии, доктор филологических наук, профессор Мартин Хартманн был известен среди европейских востоковедов как ученый, глубоко изучавший языки, литературу, историю, государственный строй, политику и экономику Востока.

\section{Materials and Methods}

Хартманн родился в 1851 году в городе Бреслау в семье священника протестанта.[1] Все пятеро детей в семье были хорошо образованы и воспитаны. Поэтому маленький Мартин первоначальное образование получил у братьев и отца в доме. Позднее он учился в лицее Элизабет города Бреслау. Окончив школу, он поступил на факультет теологии Лейпцигского университета. Однако начавшаяся в 1871 году война между Германией и Францией заставил его досрочно завершить учёбу, так как его призвали в армию. На войне он участвовал дьяконом. После войны Хартманн проучился три семестра в Бреслауском университете. Здесь он глубоко изучил историю мировых релегий и закономерности их распространении по миру. Интерес к литературе исламских стран, к истории, изучению нравственно-духовных воззрений выдающихся мыслителей этого старого мира поставил перед ним задачу глубокого изучения восточных языков. Он поступил на факультет восточных языков Лейпцигского университета. В университете он изучил арабский, персидский, древний и новый еврейский, а также языки народов европейских стран.

Уже со студенческих лет Хартманн завоевал уважение преподавателей и находился под опекой семьи руководителя семинарии известного ученого арабиста профессора Флайшера. Флайшер оказал моральную и материальную поддержку 
нескольким одаренным студентам. Среди них был будущий ученый - исламовед Игназ Гольдциер, который долгое время был другом и партнером.

В 1876 году 25 летный Хартманн защищает диссертацию на тему «Образование множественного числа в семитских языках» (Pluralbildung in semitischen Sprachen) и получает ученую степень доктора филологических наук. После этого непродолжительное время он работал в качестве драгомана - военного переводчика и канцлера в консульствах Германии в Адрианаполе и в Стамбуле, позже в Бейруте. В Бейруте Хартманн работал до 1887 года. За время службы в Аравии он познакомился со многими арабскими политиками, философами, поэтами, деятелями искусства и культуры. У них он изучал в первую очередь арабскую, тюркскую и персидскую устную и письменную литературу, а также историю.

После увольнения с консульства, Хартманн был принят на должность преподавателя арабского языка в семинарии восточных языков Берлинского университета, где он снискал уважение как старательный преподаватель и талантливый ученый. Однако, некоторая его грубость и чрезмерная требовательность не позволили ему подняться на более высокие должности. Тем не менее, за свою педагогическую деятельность он воспитывал много учеников, которые впоследствии внесли огромный вклад в развитии востоковедения в Европе. [16]

До конца своей жизни - в течение 31 года Хартманн работал в семинарии. Он прошел путь от преподавателя до заведующего кафедрой и позднее до руководителя семинарии. За время работы Хартманн организовал много научных командировок по странам Европы и Востока. Он путешествовал от Сицилии до краев восточного Туркестана.

За свою творческую деятельность ученый собрал сотни рукописей и камнетесных книг по востоковедению. Его коллекция считался самым богатым собранием в Европе и библиотека всегда была полна учеными и его учениками. Несмотря на это Хартманн разослал в различные газеты и журналы материалы о коллекциях своих книг.[6; 11]

Одно из первых крупных исследований Хартманна посвящено устному народному творчеству тюркских народов и представляет собой крупную статью, посвященную исследованию формирования образа Ходжи Насреддина в фольклоре народов Востока, его развития, распространения в литературы других народов и перевода на языки Европы. Как отмечается в статье, анекдоты про Насреддина Афанди представляют собой образцом устного народного творчества тюркских и арабских народов, часть из них формировалась как материал арабского фольклора в V-VI веках. Начиная с XII века они перешли из арабского языка в тюркский, а в последующих веках наоборот, с турецкого на арабский язык. Однако точное определение генезиса многих анекдотов невозможно. [2]

В статье представлены сведения о рукописных книгах, рассказывающих о фольклоре арабских и тюркских народов, в которых представлены также классификация анекдотов по содержанию и идеологической направленности, и на этой основе они разделены на три группы. В обширной статье Хартманн приводит материал об ученых - предшественниках, долгое время работавших над этой темой, а также выражает свое отношение к их творчеству. В статье представлена подробная информация об авторах, первоначально переводивших эти рассказы на Западные языки, в частности, на французский язык.

Хотя Хартманн был известен в Европе как арабист и «Коранфоршер» (исследователь корана), у него были достаточно много работ по тюркологии. В особенности его произведения о творчестве турецких поэтов и писателей используются в Турции и в настоящее время. В книге представлены материалы о творчестве более 200 тюркских поэтов и поэтесс, живших в XIX и XX веках, приведены некоторые их портреты и отрывки из созданных ими произведений. [3]

Ученый в период с 1900 года по 1910 год занимался центральноазиаведением. В этот период в Европе снизился интерес к тюркологии. Многие востокове- ды, после секретного путешествия Херманна Вамбери в 1865-1867 годах в Центральную Азию, сочли бесполезным занятие тюркологией, и основное внимание направили на изучение арабского, персидского, китайского и индийского языков. Было “предсказано" также, в ближайшее время о польном переходе населения исламских стран в христианство. Некоторые востоковеды, в том числе Херманн Вамбери, давая высокую оценку творчеству узбекских поэтов - классиков как Навои, Бобур, Машраб, Мунис и другие, отметили что, ...в их газелях прославляются идеи кочевников. [12] Тем самим и Вамбери считал узбекский народ кочевником. Многие востоковеды Европы стали подражать этой трактовке, и начинали свои произведения о генезисе узбекского народа словами Вамбери. Таким образом в Европе сформировалось неверное представление об узбеках. Однако, Хартманн категорически отрицал эту мысль: "...выражая свое уважение к господину Вамбери, путешествовавшим босиком и с риском для своей жизни в Центральную Азию, возражаю против его взглядов на эту проблему. В стихах Машраба я не встретил никаких идей кочевых народов. Его 
газели пропитаны высоким исскусством поэзии." [8,108] Хартманн создал более 30 крупных произведений по центральноазиаведению. Особенно его учебник, созданный для любителей чтения литературы на узбекском языке, в котором были представлены отрывки из произведений великих мыслителей Востока как Ахмад Яссави, Алишер Наваи, Шермухаммад Мунис, способствовало оживлению в Европе деятельности по тюркологии.

В этой книге Хартманн приводит многочисленные сведения об узбекском народе и его городах. Критикуя ставшую традиционной точку зрения тенденцию именования языка большей части населения Туркестана - узбекского “чагатайским языком”, ученый пишет: ... Назвать этот язык “чагатайским” неправильно. На данном языке, получившим свое название по имени одного из сыновей Чингиза Чагатай, создавались великие произведения еще за 160 лет до монгольского нашествия. Это и есть “Кутадгу билиг”! (Дорога к знаниям). Хотя и Радлов считал что это произведение написано на уйгурском языке, неверно. Юсуф хос Ходжиб писал свое произведение на арабском алфавите. Что же касается его экземпляра на уйгурском языке, то он переведен в те годы, когда один из врагов Чингизхана - Тажанг назначил секретаря уйгурской национальности своим хранителем печати и наставником своих сыновей. [8, 135]

\section{Conclusion}

Хартманн внес огромный вклад в мировое машрабоведение. Он является путешественником, организовавшим экспедицию за счет своих личных сбережений по местам проживания Машраба. В период с сентября 1902 года и по апрель 1903 года им проведены серьёзные исследования в Узбекистане, Киргизии и Китайском Туркестане. В Кашгаре - столице восточного Туркестана, совместно с местными литераторами он осуществил художественностилистический анализ “Девони Машраб" (сборник рассказов о его жизни и стихов), изучил местные диалекты, рассказы и сказания древних народов Востока и опубликовал свои статьи в специальных журналах Германии. В статье "Кадамжой” (свяшенное место) он дает ценную информацию о священных местах и местах паломничества связанные с именем Машраба в межгорьях Киргизии и Китая. Имеется также информация о формировании этих мест и об изменении способов поклонения с течением времени. [4] По итогам турне по Центральной Азии ученым - путешественником написаны другие статьи и книги. Статьи "Кукольный базар в Бухаре" (Puppenmarkt in Buchara) [5], “Чагатайский диван Хувайдо" (Der Caghataische Divan Huveidas) [9], “Полиграфия в Туркестане и собрания тюркских книг Хартмана" (Das Buchwesen in Turkistan und die turkischen Druecke der Sammlung Hartmanns), [6] научный трактат "По Азии" (Durch Asien), [7] статьи рассказывающие об истории города Ташкента, перевод на немецкий язык книги о родословне наставника Машраба Афак ходжи ишана “Тазкираи азизон” - Хрестомания святых (Taskirai asison von Muchammad Sadiq) [10] относится к их числу.

Хартманн в последствии также поддерживал связь с Туркестаном. В период работы в Германском радио "Передачи для стран Востока" он переписывался с выдающимся мыслителями Востока. Чтобы создать радио пришлось продавать всю свою коллекцию книг. Эти книги сейчас находятся в различных государственных и личных коллекциях и музеях мира.

Хотя и Хартманн прожил недолгую жизнь (умер в 1918 году), его дело продолжается последователями, открывающими новые грани в Европейском востоковедении.

\section{References:}

1. Ludmila Hanisch (2000) "Machen Sie unseren Islam nicht gar zu schlecht”. Der Briefwecksel der Islamwissenschaftlar I. Goldzieher und M. Hartmann.-Otto Harrasowitz Verlag.

2. Hartmann Martin (1895) Schwaenke und Schnurre im islamischen Orient.// Zeitschrift fuer Volkskunde.-Berlin:Verlag von Ascher \&Co. -p.40-67.
3. Hartman M. (1917) Die Literatur der neuen Türkei.- Leipzig: O. Harrassowitz. Katalog 377.

4. Hartmann M. (1903) Chademğai.// Orientalische Literaturzeitung.-Berlin.

5. Hartmann M. (1903) Der Puppenmarkt in Buchara. // OLZ.

6. Hartmann M. (1905) Das Buchwesen in Turkistan und die tuerkischen Druecke der 


\begin{tabular}{l|lr|ll|ll} 
& ISRA (India) & $=\mathbf{1 . 3 4 4}$ & SIS (USA) & $=\mathbf{0 . 9 1 2}$ & ICV (Poland) & $=\mathbf{6 . 6 3 0}$ \\
Impact Factor: & ISI (Dubai, UAE) $=\mathbf{0 . 8 2 9}$ & PUHL (Russia) $=\mathbf{0 . 2 0 7}$ & PIF (India) & $=\mathbf{1 . 9 4 0}$ \\
& GIF (Australia) & $=\mathbf{0 . 5 6 4}$ & ESJI (KZ) & $=4.102$ & IBI (India) & $=\mathbf{4 . 2 6 0}$ \\
& JIF & $=\mathbf{1 . 5 0 0}$ & SJIF (Morocco) $=\mathbf{2 . 0 3 1}$ & & \\
\hline
\end{tabular}

Sammlung Hartmanns. Westasiatische Studien. WSOS zu Berlin. Spr.539.

7. Hartmann M. (1907) Durch Asien. Berlin.

8. Hartmann M. (1901) Der weisse Narr und fromme Ketzer. // Der islamishe Orient.Heidelberg: Carl Winter`s Universitätsbuchhandlung. $-48 \mathrm{p}$.

9. Hartmann M. (1902) Der čaghataische Divan Hủweda`s.//Westasiatische Studien. - Berlin. p. $132-155$.

10. M.Hartmann.(1905) Taskirai asison von Muchamad Sadiq. Ein Heiligenstaat im Islam.Berlin: Wolf Preiser Verlag. Uebersetz von
11. Hartmann M. (1904) Ostturkische Handschriften der Sammlung Hartmanns.// Westasiatische Studien. -MSOS zu Berlin, p.1-21.

12. Vambery H. (1892) Zwei moderne centralasiatische Dichter Munis und Emir.// WZfKdML. Wien. SA.

13. Martin Hartmann (2017) Available: https://en.m.wikipedia.org.wiki (Accessed:12.12. 2017г.) 